\title{
The new era of foot and ankle surgery research in Latin America
}

\author{
Nova era da pesquisa científica na cirurgia do tornozelo e pé na América Latina
}

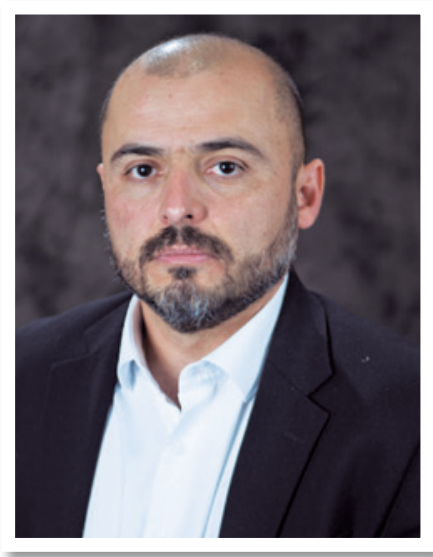

Marco Túlio Costa President of ABTPé 2018/2019

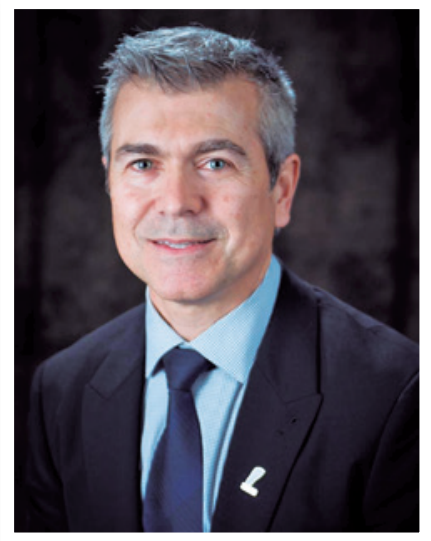

José Antônio Veiga Sanhudo President of ABTPé 2020/2021
Dear readers, during the last few years, ABTPé executive and editorial boards have been working hard to improve our journal, having recently received help and support from friends in Latin America, Portugal, and Spain.

With the main goal of indexing our journal in renowned scientific databases and to further reduce production costs, last year, the executive board of ABTPé, the editorial board of the journal, and partners from Latin America and the Iberian region started a process to merge periodicals.

Such integration will be completed in January 2020, and our journal will become more comprehensive, stronger, and more likely to be accepted in new scientific databases. This process required changes throughout the editorial board, which were concluded during December. Professor Alexandre Leme Godoy-Santos, PhD, was appointed as the new Editor-in-Chief of the journal, and the new Editorial Board was formed with the contribution of all countries involved.

This process is a strategic global positioning action for Brazil - ABTPé - and for the Region - FLAMECIPP, further representing an advance in the partnership with Portugal and Spain.

We thank Dr. Jorge Mitsuo Mizusaki and his team for the exceptional work done in leveraging our journal.

We also appreciate the trust and fundamental support provided by our Editorial Board (2007-2019), represented by Professor Manlio Mario Marco Napoli, PhD, Professor Osny Salomão, PhD, Professor Sérgio Bruschini, PhD, Professor Roberto Santin, PhD and Dr. Egydio de Carvalho, who understood that the journal's evolution involves a greater international visibility.

We wish the new team success and an excellent job in taking the new journal to even higher levels.

\section{NEW EDITORIAL BOARD:}

- Alexandre Leme Godoy-Santos - Brazil

- Cristian Ortiz - Chile

- Daniel Baumfeld - Brazil

- Gabriel Khazen - Venezuela

- Luis Hermida - Mexico

- Marcelo Pires Prado - Brazil

- Marco Túlio Costa - Brazil

- Mario Herrera - Spain

- Pablo Sotelano - Argentina

- Paulo Felicíssimo - Portugal

- Santiago Guerrero - Colombia 


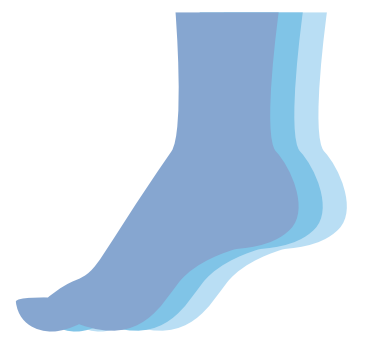

Scientific Journal of the
Foot \& Ankle 